\title{
LEGAL THEORY AND THE ECONOMIC ANALYSIS OF TORTS AND CRIMES
}

\author{
Alvin K. Klevorick*
}

\section{INTRODUCTION}

One has to be impressed by the volume of research produced in the last fifteen years that has applied economics to analyze legal issues -in particular, the subjects of torts and crimes. The nature of the inquiry has been diverse. It has included normative analysis of the implications that economics has for the design of a particular rule of law 1 as well as positive analysis, using economic arguments, of why the common law has taken the form it has. ${ }^{2}$ The economic approach has featured both theoretical analysis 3 and empirical work ${ }^{4}$ on legal issues. The literature has developed not only in publications explicitly devoted to law and economics 5 but in law reviews and leading economics journals as well. Volumes have been produced that provide comprehensive

* Professor of Law and Economics, Yale University. I would like to thank Bruce Ackerman, Ian Ayres, Jules Coleman, Robert Ellickson, Owen Fiss, Susan Rose-Ackerman, Steven Shavell, and Judith Thomson for helpful discussions and for their comments on an earlier draft of this Article. I am also very grateful to Gene Schaerr for his helpful research assistance. These people, of course, bear no responsibility for any faults that remain.

1. See, e.g., G. Calabresi, The Costs of Accidents (I970); R. Posner, Economic Analysis of Law (2d ed. 1977).

2. See, e.g., R. Posner, supra note 1, at 179-91; Priest, The Common Law Process and the Selection of Efficient Rules, 6 J. Legal Stud. 65 (1977); Priest, Selective Characteristics of Litigation, 9 J. Legal Stud. 399 (1980); Rubin, Why is the Common Law Efficient?, $6 \mathrm{~J}$. Legal Stud. 51 (1977).

3. See, e.g., Becker, Crime and Punishment: An Economic Analysis, 76 J. Pol. Econ. 169 (1968); Brown, Toward an Economic Theory of Liability, 2 J. Legal Stud. 323 (1973); Diamond, Single Activity Accidents, 3 J. Legal Stud. 107 (1974); Polinsky, Strict Liability vs. Negligence in a Market Setting, 70 Am. Econ. Rev. (Papers \& Proc.) 363 (1980); Polinsky \& Shavell, The Optimal Tradeoff Between the Probability and Magnitude of Fines, 69 Am. Econ. Rev. 880 (1979); Shavell, Damage Measures for Breach of Contract, 11 Bell J. Econ. 466 (1980); Shavell, On Liability and Insurance, 13 Bell J. Econ. 120 (1982); Shavell, Strict Liability Versus Negligence, 9 J. Legal Stud. 1 (1980); Spence, Consumer Misperceptions, Product Failure and Producer Liability, 44 Rev. Econ. Stud. 561 (1977).

4. See, e.g., Ehrlich, The Deterrent Effect of Capital Punishment: A Question of Life and Death, 65 Am. Econ. Rev. 397 (1975); Ehrlich, Participation in Illegitimate Activities: An Economic Analysis, in Essays in the Economics of Crime and Punishment 68 (1974); Landes, Insurance, Liability, and Accidents: A Theoretical and Empirical Investigation of the Effect of No-Fault Accidents, 25 J.L. \& Econ. 49 (1982); Posner, A Theory of Negligence, $1 \mathrm{~J}$. Legal Stud. 29 (1972); Priest, A Theory of the Consumer Product Warranty, 90 Yale L.J. 1297 (1981).

5. Among these are the International Review of Law and Economics, the Journal of Law and Economics, the Journal of Legal Studies, and the Journal of Law, Economics, and Organization (forthcoming). 
treatment of recent work on economic analysis of law in general ${ }^{6}$ or give detailed attention to particular areas. ${ }^{7}$

In addressing this symposium's subject of new directions in law and economics, I shall assume that at least the broad characteristics of this literature are known and confine my discussion to some observations about an aspect of our enterprise that needs more attention.

Stated most generally, the point I want to emphasize is that economic analysis of any issue does not take place in a vacuum. In particular, law-and-economics analyses are confined by political institutions, moral norms, social conventions, and widely shared beliefs about the rights and obligations of members of a society and of the society itself. The problems addressed in law and economics are themselves structured by those institutions, principles, and convictions. This noneconomic foundation has implications for the way we who work in law and economics do our research and for the way we ought to understand the results of that research.

Section I begins with an argument that I have made elsewhere about the central role of political, legal, and moral presuppositions in any theory of the criminal category, even an economic one, and then explains how the same point applies more broadly to all economic analysis of law. In Section II, I illustrate this point in the context of a society's choice of legal rules to control some set of harms that its members may visit upon one another. Finally, Section III indicates how a particular noneconomic basis for society's distinguishing among harms and harm-generating activities, namely the moral culpability of the injurer's bebavior, introduces new elements into the previous section's analysis.

\section{Noneconomic Foundations of the Economic AnAlysis OF LAW}

In a previous paper, I argued that the economists' literature on crime is inherently incomplete. ${ }^{8}$ The problem arises in the efforts of law-and-economics scholars to explain the existence of the criminal cat-

6. See, e.g., W. Hirsch, Law and Economics: An Introductory Analysis (1979); J. Oliver, Law and Economics: An Introduction (I979); A. Polinsky, An Introduction to Law and Economics (1983); R. Posner, supra note 1; G. Tullock, The Logic of the Law (I97I). For a valuable introduction to some of these works, see Cooter, Law and the Imperialism of Economics: An Introduction to the Economic Analysis of Law and a Review of the Major Books, 29 UCLA L. Rev. I260 (I982).

7. See, e.g., R. Anderson, The Economics of Crime (1976); Economic Foundations of Property Law (B. Ackerman ed. 1975); The Economics of Contract Law (A. Kronman \& R. Posner eds. 1979); Economics of Corporation Law and Securities Regulation (R. Posner \& K. Scott eds. I980); The Economics of Medical Malpractice (S. Rottenherg ed. 1978); K. Elzinga \& W. Breit, The Antitrust Penalties: A Study in Law and Economics (I976); W. Luksetich \& M. White, Crime and Public Policy: An Economic Approach (1982); L. Phillips \& H. Votey, The Economics of Crime Control (1981).

8. Klevorick, On the Economic Theory of Crime, in Nomos XXVII: Criminal Justice 289 (J. Pennock \& J. Chapman eds. I985). 
egory-to explain why we distinguish a set of acts that we call crimes. The incompleteness exists, I argued, because any economic theory of crime depends on and is confined by a set of legal and political presuppositions. 9

Essentially, the economic explanations of the criminal category say that acts are characterized as crimes if the actor tries to set conditions under which a transfer of entitlements will occur and those conditions do not conform to the ones society has stipulated. Society refuses to accept the actor's efforts to redefine the terms of transfer. The two principal contributions that draw upon economic analysis to explain why a society distinguishes a set of acts as crimes provide narrower reasons for the distinction. Richard Posner argues that the criminal sanction is used to induce individuals to engage in voluntary rather than coercive transactions with one another when voluntary ones are feasible at low enough cost. For Posner, acts are categorized as crimes and treated accordingly because society wishes to direct transactions into market settings whenever that is economically feasible. ${ }^{10}$ Guido Calabresi and Douglas Melamed suggest that particular acts are distinguished as crimes, for which special sanctions are imposed, because society needs to prevent individual members of society from changing property rules and inalienability rules into liability rules at their individual discretion. ${ }^{11}$

Both Posner's and Calabresi and Melamed's explanations are, as I have argued elsewhere, too restrictive. ${ }^{12}$ For example, a society that makes the buying and selling of votes a crime imposes the criminal sanction on someone who, in Posner's terms, substitutes a market transaction for a nonmarket transaction, and in Calabresi and Melamed's terms, converts an inalienability rule into a property rule. This is the reverse of what both Posner's and Calabresi and Melamed's models of the criminal category suggest. A society might also bring the criminal sanction to bear on someone who, in Calabresi and Melamed's terminology, converts a liability rule into a property rule, instead of the other way around, as their model suggests. This would be the case, for example, if the society decides that all pollution control requirements should be imposed in a collective manner, so that entitlements to be free from pollution are protected by a liability rule, and makes it a crime for a polluter to "bribe" individual pollutees to tolerate higher emission levels.

Because of these possibilities, which are excluded from the Posner and the Calabresi-Melamed analyses, it is desirable to reformulate the economic explanation in more general terms. An act is a crime because

9. Id. at 290, 301-04.

10. See R. Posner, supra note 1 , at 163-72.

11. See Calabresi \& Melamed, Property Rules, Liability Rules, and Inalienability: One View of the Cathedral, 85 Harv. L. Rev. 1089, 1124-27 (1972).

12. Klevorick, supra note 8 , at 301-03. 
the actor behaves in a way that is contrary to what I call the transaction structure that society has established. This structure sets out the terms or conditions under which particular transactions or exchanges are to take place under different circumstances. Under this economic explanation, the criminal sanction is employed to enforce the transaction structure that society has chosen as well as to charge the offending actor for the harms that his action imposes on individuals within the society. This charge includes whatever monetary and nonmonetary penalties are imposed on the criminal; there is no assumption that the fine, if there is one, will be used to compensate the victims for the harms they have suffered. The sanction imposes a penalty on the criminal for his effort to secure an unfair advantage by seeking to avoid complying with the transaction structure-including the laws of property, contract, and tort-to which the other members of society conform their conduct.

An explanation of why some acts are crimes while others are not therefore requires an inquiry into how the society legitimates its transaction structure. What is the source of the political power that gives the collectivity the right to decide the terms on which particular transactions will take place? Why does the right to structure some transactions rest with the individual while the form of others is determined by the collectivity? What moral judgments of the society make some acts criminal? These are questions that neither economists nor economic analysis has a comparative advantage in answering.

This type of inquiry is from the analyst's point of view positive, not normative, in nature. That is, how a society legitimates its transaction structure forms part of a theory that explains the existence of the criminal category for that society. To be sure, the analyst could raise these same questions on a wholly normative, not descriptive, level. An outside observer with an independent set of values could assess the justifications offered by a society for classifying certain acts as criminal. The analyst might decide that the rules society established to govern transactions were indefensible in light of his set of exogenous values. The evaluative enterprise of this outside observer is very different from the explanatory inquiry that is needed to derive a theory of crime for a specific society, taking that society's normative judgments as given.

The law-and-economics explanation of the criminal sanction presupposes the existence of a transaction structure. For any particular society, one will observe a set of acts being considered crimes; from this one can infer that these acts are contrary to the society's transaction structure. But explaining a particular society's transaction structure requires an understanding of societal values-a conception of how a society legitimates its transaction structure. This, too, is a descriptive inquiry concerned with the actual moral, political, and legal commitments of the particular society rather than with norms derived by appeal to abstract moral argument. 
The need to answer questions about legitimation of the transaction structure to explain the existence of the criminal category implies that although an explanation of why society invokes the criminal sanction can be stated in economic terms, that vocabulary and mode of analysis do not provide a complete substantive understanding. To the contrary, a coherent explanation of the criminal category necessitates answers to noneconomic questions about political legitimacy and authority, about the rights of individuals and the power of the state, about the political, moral, and legal constraints on the exercise of rights and powers. A prerequisite to undertaking a full microeconomic analysis of crime is a certain minimum of information about political and legal foundations.

In commenting on this argument, Judge Posner has observed that a theory of rights underlies the economic analysis of torts as much as it provides the infrastructure for the economic theory of crime. ${ }^{13} \mathrm{He}$ argues that we should not wait for the development of consensus on a political theory of rights in our society before undertaking economic analysis of crime. Judge Posner seems to have focused on the prescriptive role of a theory of rights in an economic theory of crime whereas I am emphasizing the analytic or descriptive role of such a theory-the way in which an understanding of legal and political norms in a society provides the foundation for an economic theory of crime applicable to that society. But his argument does point up a way in which I overdrew the distinction between the economic theory of crime and the economic theory of other branches of law, particularly torts.

What I have argued about the economic theory of crime applies to other areas of law as well: a minimal legal and political foundation must be posited before one can pursue any law-and-economics analysis as that analysis is currently undertaken. This observation emerges most saliently in considering the economists' or the lawyer-economists' literature on crime precisely because the law in that area is, from an economic perspective, addressed to acts contrary to, or assaults upon, the transaction structure. It applies with equal force in other areas as well, but is less apparent in relation to them because in areas like torts, contracts, and property the transaction is more easily identified, and the economic analysis concerns actions taken in conformity with the transaction structure. Hence, in those areas, questions of the legitimacy of that transaction structure and the political, moral, and legal constraints upon it do not come so strongly to the fore.

Because any microeconomic analysis of law presupposes answers to noneconomic questions and presumes features of the political, moral, and legal landscape, we must recognize the conditional nature of the results of such analysis. A change in the underlying legal and political presuppositions may lead to a different conclusion concerning

I3. Posner, Comment on "On the Economic Theory of Crime," in Nomos XXVII: Criminal Justice 310, 310 (J. Pennock \& J. Chapman eds. 1985). 
the effects or the desirability of the particular rule of law that economic analysis is being used to illuminate. Hence, our analyses should examine how our results change when plausible alterations are made in the (sometimes implicit) assumptions about the legal and political setting. Moreover, in formulating models of particular legal problemsfor example, the optimality of different liability rules or the optimal combination of probability and severity of punishment-we should be attentive to and should incorporate prevailing conceptions of the basic moral, political, and legal structure.

Perhaps an analogy will help here. When John Rawls' $A$ Theory of Justice ${ }^{14}$ appeared, it gave rise to a flurry of articles that reconsidered economists' policy recommendations when a "maximin" welfare function, derived from a narrow reading of Rawls, replaced the more conventionally used utilitarian objective function. Such analyses were undertaken in areas like taxation ${ }^{15}$ and consumption of exhaustible resources. ${ }^{16}$ The enterprise has abated, and my point is not that it should have expanded to cover every problem that economists ever considered. Quite to the contrary, the enterprise was on the right track because it inquired about the possible economic effects of an alternative political theory in precisely those areas where differences about the fundamental structure of society were most likely to be regarded as important.

I do not mean to reopen the debate about the appropriate definition of efficiency or the coherence of particular objective functions-for example, wealth maximization ${ }^{17}$ - that have been frequently used in the law-and-economics literature. What I do want to argue is that there are alternative plausible social objective functions and social constraints that should be recoguized, and that our policy recommendations may well depend on which of these we employ. Consequently, in placing one or another objective function at the center of our analysis our choice should be informed by what we know about the relevant underlying societal structure, and we should engage in comparative-statics analysis at the basic institutional level, always making clear the assumptions that underlie the analysis. The sensitivity of our results to different conceptions of the basic legal and political structure should be examined. This is especially important because in many of the situations to which law-and-economics analysis is directed, the separation of

14. J. Rawls, A Theory of Justice (1971).

15. See Atkinson, How progressive should income tax be?, in Essays in Modern Economics 90 (1973); Phelps, Taxation of Wage lncome For Economic Justice, 87 QJ. Econ. 331 (1973); Sah, How Much Redistribution is Possible Through Commodity Taxes?, 20 J. Pub. Econ. 89 (1983).

16. See Solow, Intergenerational Equity and Exhaustible Resources, 41 Rev, Econ. Stud.: Symposium 29 (1974).

17. For a good introduction to the debate, see Symposium on Efficiency as a Legal Concern, 8 Hofstra L. Rev. 485 (1980); A Response to the Efficiency Symposium, 8 Hofstra L. Rev. 811 (1980). 
efficiency considerations and distributional considerations, broadly construed, is not well grounded in economic theory. That is, problems in law and economics often arise precisely when the conditions under which the basic theorems of welfare economics, which allow the separation of issues about the "size of the pie" from issues about how it is divided, do not obtain. ${ }^{18}$

The features of the essential legal and political structure most often taken for granted in a law-and-economics analysis cover a wide range. Some examples are: Whose utility should count in the analysis-should a tortfeasor be accorded treatment different from that given to a criminal? How many distinctions is society willing to make among people, among activities, among acts; and how does the fineness of the distinction drawn differ with the purpose to which it is put? When does the society recognize differences in types of harm-causing behavior?

\section{Negligence Versus Strict Liability: An Example}

Let me use a familiar setting to illustrate the ways in which assumptions about the legal and political structure of a society condition the results of law-and-economics analysis. Specifically, how will a society's willingness or unwillingness to draw distinctions among people based on particular characteristics affect the choice of a liability rule for that society?

Suppose that individuals who engage in some activity suffer no harms themselves but may harm those who do not participate in the activity. Call the former "injurers" and those who suffer harms "victims." Note that we have said nothing about the nature of the activityfor example, whether in our legal system the activity would give rise to an action in tort, a criminal prosecution, or both. To keep matters simple, assume that both sets of individuals are risk neutral.

We will assume that victims can take no steps to prevent or to mitigate the harms they may suffer. lnjurers, on the other hand, can affect the probability and severity of the losses that victims suffer. ${ }^{19}$ lnjurers derive benefits from engaging in the activity, which we furthermore assume they undertake at exogenously given and fixed levels. Taking care to reduce the likelihood or intensity of the harms injurers may create reduces the benefits they derive from the activity, and the decrease in benefits is directly related to how much care is taken.

Finally, while 1 will assume that victims are identical, I will suppose that injurers differ in a crucial characteristic that manifests itself in im-

18. For a cogent development of this theme, see Polinsky, Economic Analysis as a Potentially Defective Product: A Buyer's Guide to Posner's Economic Analysis of Law, 87 Harv. L. Rev. 1655 (1974).

19. These are what Shavell has termed unilateral harms. Shavell, Strict Liability Versus Negligence, 9 J. Legal Stud. 1 (1980). 
portant ways in our setting. First, injurers who differ in this characteristic have different abilities to take care. If each of them expends the same effort to reduce the probability or severity of harm, both the resulting reductions in expected losses to victims and the marginal returns to additional effort will differ. Second, when they take the same loss-prevention and loss-reduction measures, injurers who differ in this characteristic derive different levels of benefits from engaging in the activity and incur different decreases in benefits from small increases in their care-taking efforts. Because of these differences among injurers, the society's attitude toward drawing distinctions based upon the crucial characteristic will affect its selection of an approach to controlling the harms being considered here. Moreover, let us assume that it is very easy to observe variations in this crucial characteristic among injurers and that the relationship between this characteristic and its effect on the benefits and costs of injurer care-taking is deterministic. In other words, there is no random variation in the effects of a given care level being exercised by injurers with a particular level of this characteristic.

A standard law-and-economics approach to analyzing the optimal way to control harm-causing activity in the setting just described would posit as the welfare criterion the benefits injurers derive from engaging in the activity minus both the expected losses victims suffer and the costs of taking care. Expressed differently, the goal would be the minimization of the expected costs of harms and the costs of avoiding harms where the avoidance cost is measured by the decrease in injurers' benefits caused by their taking care. This formulation abstracts from issues of distributional equity as it assumes that equal weight is given to the benefit or cost experienced by each actor, whether he is an injurer or a victim. Consequently, this analytical structure does not encompass any distributive grounds for choosing one harm control system rather than another, although distributive reasons are undoubtedly important in the choices societies actually make.

Let $x$ denote the expenditure of effort on care, and let $k$ be an index, running from 0 to 1 , that measures what I have referred to as the crucial characteristic that differs among injurers. The ability to take care is related to $k$. Denote by $u(x, k)$ the income equivalent of the benefits that an injurer with characteristic level $k$ derives from engaging in the activity when he expends effort $x$ on taking care. Finally, let $p(x, k)$ be the probability that an injurer of characteristic level $k$ who takes care at level $x$ injures a victim; and let $h(x, k)$ be the income equivalent of the harm that a victim suffers if he is injured by a $k$-type injurer exercising care level $x$. Since all agents are assumed to be risk neutral, however, we can combine the probability of harm and severity of harm and speak only of the expected losses, denoted $c(x, k)$, of a victim in an interaction with an injurer of characteristic $k$ and care level $x$.

I assume, as stated earlier, that both $u(x, k)$ and $c(x, k)$ are strictly decreasing in $x$; and I assume, as a matter of convention, that $u(x, k)$ is 
strictly increasing in $k$. The only assumption about how $c(x, k)$ varies with $k$ is that the partial derivative $c_{k}(x, k)$ is nonzero almost everywhere: that is, for almost any $(x, k)$ pair, a small change in $k$ will change the expected losses. Next, as indicated earlier, assume that changes in characteristic level $k$ affect both the marginal social benefit of taking care (the marginal reduction in expected losses to victims, $c_{x}(x, k)$ ) and the marginal social cost of taking care (the marginal reduction in injurers' benefits, $\left.u_{x}(x, k)\right)$. Finally, for technical simplicity, suppose that both $u(x, k)$ and $c(x, k)$ are smooth functions (at least twice continuously differentiable) and that $u(x, k)$ is strictly concave while $c(x, k)$ is strictly convex.

Since the purpose of this model ${ }^{20}$ is illustrative, make one more simplifying assumption: all interactions between injurers and victims occur in unique pairs-one injurer interacts with only one victim and vice versa. Hence, if $f(k)$ denotes the frequency with which characteristic $k$ occurs in the population of injurers-that is, $f(k)$ is the probability density function of the characteristic-the social welfare function in our example is:

(1) Maximize $\int_{0}^{1}\{u[x(k), k]-c[x(k), k]\} f(k) d k$,

where $x(k)$ denotes the level of care taken by an injurer of characteristic $k$.

It is apparent that the social welfare function in (1) can be maximized term by term so that in the socially optimal solution we would have an injurer with characteristic $k$ exercising the care level that solves the problem

(2) Maximize $u(x, k)-c(x, k)$. $x \geqq 0$

Assuming that it is socially optimal for each injurer to exercise some care, the social optimum or first-best arrangement is for an injurer of characteristic $k$ to choose the care level that satisfies

(3) $u_{x}(x, k)-c_{x}(x, k)=0$.

That is, each type of injurer should simply be operating at that care level at which the marginal social cost of his caretaking is equal to the marginal social benefit of his efforts. ${ }^{21}$ Denote by $x^{*}(k)$ the solution to equation (3)-the socially optimal level of care for an injurer whose index of the crucial characteristic is $k$.

It will not be socially optimal to have injurers with different meas-

20. The model combines features contained in a number of earlier contributions to the literature on liability rules, especially those of Steven Shavell. See id; Shavell, A Model of the Optimal Use of Liability and Safety Regulation, 15 Rand J. Econ. 271 (1984).

21. Relaxing the assumption that it is socially optimal for every type of injurer to take care requires consideration of coruer solutions but does not affect the basic point of the argument that follows. 
ures of the crucial characteristic take the same degree of care; in general $x^{*}(k)$ will vary with $k .22$ The notation and machinery may seem excessive for making this point about $x^{*}(k)$, but they do help to bring it out with clarity.

Since, by assumption, it is very easy to determine the level of the crucial characteristic associated with any individual injurer, the social optimum can be achieved under either a strict injurer liability system or a negligence system, as these are usually modelled. If a strict liability rule is in effect, an injurer must pay for all harms suffered by the victim with whom he interacts. Under strict liability an injurer with characteristic level $k$ faces precisely the problem in (2) and chooses $x^{*}(k)$ as his care level. With the negligence rule, an injurer must pay for harms if and only if his expenditure of effort falls short of the due care leveldenote it $\bar{x}$-specified by a social institution, such as a judge/jury combination. If that institution were to set the due care level for an injurer of type $k$ at $x^{*}(k)$-that is, $\bar{x}(k)=x^{*}(k)$-a $k$-type injurer would choose the care level $x^{*}(k)$, and once again the social optimum would be achieved.

In the setting as specified so far, assuming away all administrative costs, the society would be indifferent between the negligence rule and the strict liability rule insofar as both lead to the maximum of the function in (1). Recall that the posited social welfare function abstracts from distributional concerns. Hence, the fact that an injurer with characteristic $k$ pays $c\left(x^{*}(k), k\right)$ under the strict liability system and nothing under the negligence rule does not tip the scale between the two rules in either direction. Since the injurers' activity levels are exogenously given and fixed, there is in this model no reason to choose between negligence and strict liability on the ground of how much of the harmcausing activity there is or who participates in it.

Suppose now that the crucial characteristic that differs among injurers is, in fact, a characteristic that members of the society believe it is illegitimate to use as a basis for distinguishing among individuals. As part of the basic political structure, distinctions among members of the society based on their level of the $k$ index are viewed as classifications that ought not be drawn.

If the society in our example were to regard the crucial characteristic measured by the level of $k$ as an improper ground for drawing legal distinctions among people, the negligence and strict liability systems would no longer be equivalent. It would no longer be possible to tailor due care standards to levels of the crucial characteristic; instead, there would have to be one due care standard specified for everyone. ${ }^{23}$ Since

22. Had we imposed additional restrictions on the shapes of $u(x, k)$ and $c(x, k)$, we would conclude, more strongly, that $x^{*}(k)$ is a distinct value for each distinct value of $k$.

23. Taken literally, our present system of tort law appears to impose a single standard of care-the "reasonably prudent person" standard-on everyone. In fact, however, since that rule requires that the trier of fact consider what the reasonably prudent 
the optimal solution to $(1), x^{*}(k)$, varies with $k$, the negligence system constrained to satisfy $\bar{x}(k)=\bar{x}$ for all $k$ must yield a lower value of the social welfare function in (1). A negligence system with the same due care standard for everyone cannot do as well in terms of the goal specified in (1) as one in which the due care standard is tailored to the individual injurer's ability to take care, no matter what the level of the unitary standard. The strict liability rule, on the other hand, will still be able to yield the maximum value of that function as long as the legal/political prohibition in the hypothesized society is only on distinctions that are explicitly drawn among people with different values of the characteristic, and not on differences in the actual efforts they are observed to expend. If, however, the society were concerned about the actual care-taking efforts that individuals had to make because of the legal rule's operation, then the strict liability rule would be as impermissible as the negligence rule with tailored due care standards. Only legal rules that induced all injurers, regardless of their $k$ value, to take exactly the same level of care would then meet the society's constraints.

The advantage of the strict liability rule over the negligence rule in the model we have been discussing is analogous to a well known result in Shavell's work. ${ }^{24} \mathrm{He}$ considers a model of unilateral accidents between strangers in which injurers, who are identical, can vary both their activity levels and the care they exercise. Expected accident costs depend on each injurer's chosen levels of care and activity. But the activity level is not considered by the legal system in the formulation of the due care standard. Shavell demonstrates that in this situation, strict liability is efficient and superior to the negligence rule.

In Shavell's model, as in the one presented here, an important factor is omitted from the specification of the due care threshold, and this threshold is central to the negligence rule's operation. In Shavell's case this exclusion results from limitations on the competence of courts to gather and process data upon which to decide the appropriate activity level for injurers. In the current context it derives from a political or moral constraint on courts. In reality, classifications based upon suspect crucial characteristics would be not only impermissible but also functionally unreliable as a way of distinguishing among actors because of intragroup variation in care-taking ability among individuals who would be similarly classified. But this element of statistical variation has been excluded from the simplified model we have been discussing.

Any prescriptive law-and-economics analysis of a negligence sys-

person would have done under all the circumstances, the apparent unitary standard actually allows for consideration of individual circumstances and characteristics in a variety of contexts. For example, children are sometimes held to a lower standard of care than adults, and professionals are sometimes held to a higher standard than nonprofessionals. See, e.g., W. Keeton, D. Dobbs, R. Keeton \& D. Owen, Prosser and Keeton on the Law of Torts 173-93 (5th ed. 1984).

24. See Shavell, supra note 19 , at 10-14. 
tem for the hypothetical society we have constructed must take account of the kinds of legal distinctions that are and are not permitted in that society. Determining the negligence rule that solves (1) without taking into account the relevant constraints will yield a nonoptimal-indeed, an infeasible-solution for the society. The unconstrained cost-minimizing solution is not the social optimum for a society that will not draw the kinds of distinctions required by that solution.

One could argue that this inability to use the social welfare function in (1) to determine the social optimum here arises simply because we have omitted from our objective function the costs of relying on these suspect classifications. One could make this precise by noting that if we solved (1) with the appended constraints $x\left(k^{\prime}\right)=x\left(k^{\prime \prime}\right)$ for all $k^{\prime}$ and $k^{\prime \prime}$, we could determine the shadow prices ${ }^{25}$ on the constraintsthe social cost of not invoking the suspect classification. By attaching prices of these maguitudes to divergences among different groups' standards of care and incorporating the resulting costs into the objective function, the new optimal solution would emerge with $x(k)=\bar{x}$ for all $k$.

There are, however, two problems with this way of rehabilitating the pure cost minimization approach. First, it is somewhat circular to impute costs of violating constraints when those costs are only computed ex post-that is, after the constrained optimum is determined. Second, and more basically, there is a categorical distinction between a society's imposing a constraint on itself because it has a principled position that it does not want to do something and a society's simply imputing a finite price or cost to its doing that same thing. ${ }^{26}$

\section{Torts Versus Crimes: Some Implications of The Moral Dimension}

Legal and political presuppositions can have an even more fundamental effect on a law-and-economics analysis of the type illustrated in Section II. Economic analysis of the optimal way to control harm-causing activity may be profoundly affected by the legal category in which the action engendering harm is placed. To the extent that noneconomic considerations are, as I have argued, central to that categorization, they may have a major impact on the law-and-economics analysis that is undertaken. Hence, we have to ask exactly what kind of activity gives rise to the "harms" that injurers inflict and victims suffer in our example. In particular, are we analyzing a problem in tort or in crime-and does it make any difference? I would argue that whether or

25. The shadow price indicates how the optimal value of the objective function would change if the constraint were relaxed by a small amount.

26. This is, of course, a controversial proposition. For an illuminating discussion, see Coleman, Foundations of Constitutional Economics, in Containing the Economic Powers of Government (1983). 
not it makes a difference depends on the society's reasons for distinguishing among harmful actions. This section considers the possible effects that one leading noneconomic explanation of the difference between tort and crime may have on the type of law-and-economics analysis illustrated in Section II.

A large number of torts and criminal law scholars have emphasized the crucial role that moral notions play in providing an account of the criminal category. In his influential pair of articles on "Interrelations of Criminal Law and Torts," 27 Jerome Hall argued that "the most defensible position, stated broadly, is that the more general doctrines of the criminal law are founded on principles of moral culpability,"28 that the value judgments underlying torts and criminal law differ, ${ }^{29}$ and that at the heart of the criminal law is the belief "that it is just to punish those who have knowingly committed moral wrongs, proscribed by law."30 For Hall, "moral culpability is of secondary importance in tort lawimmoral conduct is simply one of various ways by which individuals suffer damage. But in penal law . . . the immorality of the actor's conduct is essential-whereas pecuniary damage is irrelevant." 31 He crisply stated his general thesis "that moral culpability should remain the essence of criminal liability, and that existing legal classifications should be reorganized on that basis." 32

More recently, in distinguishing between tort and crime as two systems of individual responsibility, Richard Epstein has emphasized the need to distinguish between accidental and deliberate harms. ${ }^{33} \mathrm{He}$ defends the position, which he attributes to Hall and Hart, "that the criminal law works best when it deals with conduct of the defendant that the law thinks worthy of moral condemnation, and that it works worst when in the name of effective social control it modifies its standards by judging actors at their peril."34 Epstein sees as the basic point that "enormous caution is needed before criminal liability is imposed and that the individual subjected to punishment should by virtue of what he has done be deserving of that punishment." 35 Other authors have also stressed the central role of moral fault in the criminal law. ${ }^{36}$

27. Hall, Interrelations of Criminal Law and Torts (pts. 1 \& 2), 43 Colum. L. Rev. 753, 967 (1943).

28. Id. pt. 1 , at 771 .

29. Id, at 775 .

30. Id, at 776 .

31. Id. pt. 2, at 971 .

32. Id. at 996.

33. Epstein, Crime and Tort: Old Wine in Old Bottles, in Assessing the Criminal: Restitution, Retribution, and the Legal Process 231, 247-48 (1977).

34. Id. at 248.

35. Id. (emphasis in original).

36. Jules Coleman similarly focuses on "the key moral notions of criminal responsibility-of guilt and fault." Coleman, Crime, Kickers, and Transaction Structures, in Nomos XXVII: Criminal Justice 313, 323 (J. Pennock \& J. Chapman eds. 1985). He contrasts "the essentially non-moral character of negligence in torts" with "the essen- 
Suppose that the hypothetical society that we have heen discussing subscribes to the view of these and other scholars that moral culpability is the essence of criminal liability. Then, although the formulation of the problem in Section II can be used to analyze society's choice of a liability rule in tort law, it may have to be modified if the harm is one for which there is criminal liability.

If the moral condemnation that the society attaches to acts that result in the harms being analyzed is severe enough, it may induce a dramatic and basic change in the analysis-a modification of the specification of the social welfare function in (1). The behavior of an actor who generates a harm that is sufficiently morally reprehensible may be regarded as so deserving of condemnation that he is viewed as an "outlaw," a pariah, perhaps even a nonmember of society. As a result, the injurer's benefits may be given less weight-perhaps even no weight at all-in the social welfare function. This is precisely the kind of change that people generally associate with a move from discussions of torts to discussions of crimes. But such a distinction cannot be derived from the standard law-and-economics approach to explaining the criminal sanction, which views criminal law as an extension of tort law. This remains true even after that approach makes all sorts of adjustments in the tort damages remedy such as incorporating detection costs into fines and replacing fines with nonmonetary penalties for judgmentproof injurers. This discounting of the injurer's benefits in the social welfare function must be rooted in noneconomic considerations. In the example in Section II, if the injurer's utility were not to count at all, this would lead to more stringent due care levels at the optimum, levels sufficiently stringent to eliminate the harm entirely. Or, if we were working with a model, like Gary Becker's, ${ }^{37}$ of optimal policy toward crime, we know from Becker's results that reducing the marginal social value of the offender's gain would lead to higher levels of both the probability of punishment and the severity of punishment.

The moral condemnation that the society attaches to the harmful acts may not be strong enough to warrant discounting the injurer's gains, but it may be enough to overcome the society's unwillingness to draw distinctions on the basis of the crucial characteristic $k$. The society's interest in assessing responsibility for acts that are sufficiently morally reprehensible may induce it to trade off its strong aversion to classifications based on the index $k$. In the context of our example, this

tially moral aspects of the conditions of responsibility in the criminal law." Id. at 326. $\mathrm{He}$, too, emphasizes the critical role in criminal law of the inquiry into whether the accused individual deserves to be punished. Id. Finally, Stephen Schulhofer has also stressed the central role that the concept of fault plays in "making decisions about criminalization, excuses, and the grading of offenses" and about the sanctioning structure as well. Schulhofer, Is There an Economic Theory of Crime?, in Nomos XXVII: Criminal Justice 329, 338 (J. Pennock \& J. Chapman eds. 1985).

37. Becker, supra note 3. 
would mean that the cost-minimizing solution, $x^{*}(k)$, would be socially optimal since the society would be willing to make explicit distinctions among people based on the crucial characteristic. Or in the context of formulating optimal policy toward crime, it might render permissible the specification of different probability-of-punishment/severity-ofpunishment combinations for individuals with different $k$ levels.

But the moral dimensions of the criminal categorization can work in the other direction as well, to countervail against any tendency to draw lines that the society deems illegitimate or morally suspect. For a society of the type we have now hypothesized, punishment for a crime carries with it moral condemnation and the implication that the person to whom punishment is meted out deserves to be punished. But, given that weighty implication, such a society may tend to impose an exceedingly demanding standard of culpability for an action it labels a crime and may be correspondingly reluctant to invoke distinctions it considers morally dubious. Similarly, since the prosecution of crimes brings the weight of the state down upon an individual member of society, we may find that the state is even more hesitant to classify individuals on the basis of suspect crucial characteristics in criminal cases.

I am not drawing any specific conclusion about how far our hypothetical society's grounding of criminal liability in moral culpability would carry it in respecifying the problem of choosing a system to cope with the harms we have been discussing. For example, some harms might be so morally condemned by the society that the injurer's utility would be severely discounted while others might result in very little, if any, discounting of the injurer's benefits. Without more information about the society in our example, we cannot be specific about the implications for the problem posed. But the central point is that information about the basic legal and political structure of the society is needed before a law-and-economics analysis of a society's harm control system can go forward.

\section{Concluding Comments}

Someone who views legal rules wholly in terms of the functions they are meant to serve would probe beyond the statement of the society's imperative that distinctions not be drawn on the basis of the characteristic indexed by $k$ and beyond the statement of a moral foundation for the criminal category. He would ask what "more basic" purpose each of these serves. Perhaps such a functionalist would attempt to argue that each of these positions could be resolved into decisions grounded in efficiency reasons and distributional preferences. I am dubious that this can be done, in particular with regard to the moral foundation of the criminal category. But to the extent that distributional judgments and even efficiency rationales are the source of these structural features, my basic point remains intact: legal and political presuppositions underlie law-and-economics analysis, and the value of our 
analyses depends as crucially on correctly specifying the basic political and legal structure of a society as it does on correctly specifying the production functions and transaction relations to which we usually devote more attention. 